\title{
PRINSIP KETELADANAN DALAM PENDIDIKAN KELUARGA MENURUT AL-QUR'AN
}

\author{
Syofrianisda \\ Islamic College of Yaptip Pasaman Barat \\ Jln. Bundo Kanduang No. 142, Simpang Empat, \\ Pasaman Barat, Sumbar 26366 Indonesia \\ Email: sofialwihdah86@gmail.com
}

\begin{abstract}
Abstrak
Penelitian ini dilatarbelakangi oleh pentingnya keteladanan dalam pendidikan keluarga berdasarkan surat Al-Ahzab ayat 59. Dalam pendidikan keluarga, keteladanan sangat berpengaruh dalam kehidupan manusia yang tak lepas dari fitrah manusia itu sendiri. Namun, pada dasarnya semua itu sudah di jelaskan Allah SWT dalam Alquran. Surat AlAhzab ayat 59 menjelaskan bagaimana prinsip keteladanan dalam keluarga dan tahaptahap dalam keteladanan dalam pendidikan keluarga sekaligus peranan keteladanan dalam pelaksanaan pendidikan agama Islam. Metode penelitian ini adalah library research atau penelitian kepustakaan yaitu dengan membaca buku-buku yang berhubungan dengan masalah yang diteliti. Hasil penelitian ini menunjukkan bahwa Allah SWT sudah menjelaskan konsep keteladanan dalam pendidikan keluarga yaitu prinsip keteladanan dalam pendidikan keluarga berdasarkan surat Al-Ahzab ayat 59 yang menjelaskan peranan pemakaian jilbab yang disampaikan Rasululullah SAW kepada istriistrinya, anak-anaknya dan ummat Islam yang dengan penyampaian pemakaian jilbab tersebut mengandung nilai-nilai keteladanan. Ummat Islam dituntut untuk selalu meneladani Rasullullah SAW yang rangkaian perilakunya mengandung nilai-nilai pendidikan. Tahap-tahap dalam pemberian keteladanan berdasarkan surat Al-Ahzab ayat 59, yaitu: dimulai dari sendiri, lingkungan keluarga, dan kaum muslimin (masyarakat). Peranan keteladanan dalam pelaksanaan ajaran Islam diantaranya sebagai metode dakwah dalam pelaksanaan ajaran Islam dengan berdasarkan Alquran.
\end{abstract}

Kata Kunci : Keteladanan, Pendidikan Keluarga, Al-Ahzab

\begin{abstract}
This research is conducted due to the importance of role model in family education based on Q.S Al-Ahzab: 59. In family education, role-model is
\end{abstract}


very influential in human life which is inseparable from human nature itself. However, basically all of that has been explained by Allah SWT in the Qur'an. Q.S Al-Ahzab: 59 explains the principle of role model and its stages in the process of family education as well as the role of role model in the implementation of Islamic religious education. The results of this study indicate that Allah SWT has explained the concept of role model in family education. The principle of exemplary in family education based on QS. Surah Al-Ahzab: 59 explains the role of the wearing veils conveyed by the Messenger of Allah (pbuh) to his wives, children and all Muslims. All Muslims are demanded to always emulate Prophet Muhammad (pbuh) with Islamic practices. The stages to be role model based on the QS. Al-Ahzab: 59 are starting from self, family environment, and the Muslim community. The role of role model in implementing Islamic teachings includes the method of $d a^{\prime} w a h$ in the implementation of Islamic teachings based on the Qur'an.

Keywords: Islamic perspective; Moral education; Tafsir Al-Misbah.

\section{A. PENDAHULUAN}

Orang tua adalah pendidik pertama dan utama yang mempunyai peranan dalam membina dan mendidik anaknya menjadi anak yang beriman, berakhlak mulia dan beribadah kepada Allah SWT. Keberhasilan anaknya dalam masyarakat tergantung kepada keberhasilannya di rumah dan di sekolah, karena dalam rumah tangga pendidikanlah yang menonjol. Orang tua yang baik memberi contoh teladan yang baik yang ditiru oleh anaknya. Karena itu, keberhasilan anak ditentukan oleh pendidikan yang diterimanya dalam keluarga. Sabda Rasulullah saw :

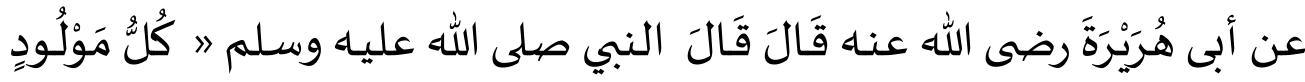

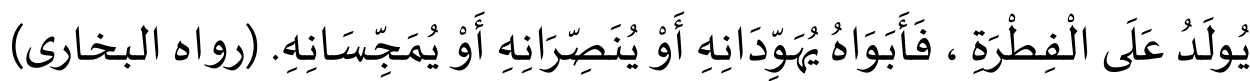 Artinya: "Dari Abi Hurairah RA, ia menceritakan bahwa Nabi saw pernah bersabda: tidak ada seorang anakpun dilahirkan melainkan dalam keadaan suci/fitrah, maka ibu dan bapaknyalah yang menjadikan Yahudi, Nasrani dan Majusi" (H.R. Bukhari). (Jamaluddin Hamidi, 1984, 89)}

Berdasarkan hadits di atas dapat disimpulkan, bahwa orang tualah yang menjadi pembina dan pendidik pertama dan utama terhadap anakanaknya yang berkaitan dengan masalah agama, baik masalah keimanan, akhlak dan maupun beribadah kepada Allah SWT.

Orang tua berfungsi sebagai sarana pertama dan utama dalam proses mendidik dan membina anak menjadi manusia beriman yang mantap, 
berakhlak mulia dan mau beribadah serta berguna bagi nusa dan bangsa. Kemudian dilihat dari keberadaan orang tua sebagai pemimpin keluarga, orang tua juga mempunyai pengaruh yang besar untuk terciptanya keluarga sakinah, mawaddah, warahmah, yaitu sebuah keluarga yang didambakan oleh setiap orang muslim. Di antara sekian banyak unsur untuk terbentuknya keluarga sakinah, mawaddah, warahmah, salah satu di antaranya adalah membina anak untuk senantiasa tunduk dan patuh terhadap peraturan dan hukum Allah SWT yang dirumuskan dalam agama, supaya menjaga diri dan keluarganya dari api neraka. Sebagaimana firman Allah SWT dalam surat atTahrim ayat 6:

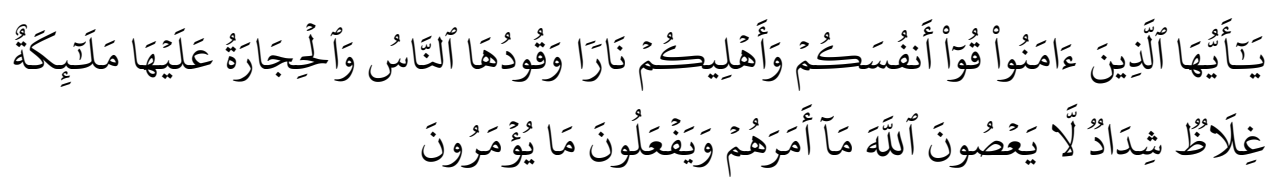

Artinya: "Hai orang-orang yang beriman, peliharalah dirimu dan keluargamu dari api neraka yang bahan bakarnya adalah manusia dan batu; penjaganya malaikat-malaikat yang kasar, keras, dan tidak mendurhakai Allah terhadap apa yang diperintahkan-Nya kepada mereka dan selalu mengerjakan apa yang diperintahkan. (Q.S. At-Tahrim Ayat 6)

Shihab (2002) menyatakan dalam tafsir Al-Misbah bahwa ayat di atas memberi tuntunan kepada kaum yang beriman, "Hai orang-orang yang beriman, peliharalah diri kamu antara lain dengan meneladani Nabi saw dan pelihara juga keluarga kamu yakni istri, anak-anak dan seluruh orang yang berada di bawah tanggung jawab kamu dengan membimbing dan mendidik mereka agar kamu semua terhindar dari api neraka”.

Ayat di atas menggambarkan bahwa pendidikan keimanan, akhlak dan beribadah harus bermula dari rumah (orang tua). Orang tua bertanggung jawab dalam menentukan masa depan anaknya. Oleh sebab itu, orang tua hendaknya menyadari akan tanggung jawab tersebut. Tanggung jawab orang tua terhadap anaknya mulai dari kandungan sampai anak tersebut dewasa dengan cara menjaga, mendidik dan menanamkan nilai-nilai agama pada anak tersebut melalui pembiasaan dan teladan yang baik. Sehubungan dengan ini Dradjat (1996: 56) menyatakan bahwa: orang tua merupakan pembina pribadi yang pertama dalam hidup anak. Kepribadian orang tua, sikap dan cara hidup mereka merupakan unsur-unsur pendidikan yang tidak langsung, yang dengan sendirinya akan masuk ke dalam pribadi anak. Perlakuan orang tua terhadap anak merupakan unsur pembinaan lainnya dalam pribadi anak.

Menurut Jalaluddin (2002), cara-cara yang praktis yang patut di lakukan oleh orang tua dalam menanamkan nilai-nilai agama pada anaknya 
adalah: 1) memberi teladan yang baik kepada mereka dengan kekuatan iman kepada Allah SWT dan berpegang dengan ajaran-ajaran agama Islam dalam bentuknya yang sempurna dalam waktu tertentu; 2) membiasakan mereka menunaikan syiar-syiar agama Islam semenjak kecil sehingga penunaian itu menjadi kebiasaan yang mendarah daging, mereka melakukannya dengan kemauan sendiri dan merasa tentram sebab mereka melakukannya; 3) menyiapkan suasana agama dan spiritual yang sesuai di rumah mereka berada. Membimbing mereka dengan bacaan-bacaan yang berguna dan memikirkan ciptaan-Nya dan makhluk-makhluk untuk menjadi bukti kehalusan sistem ciptaan itu dan atas wujud serta keagungan-Nya; dan, 4) mengikut sertakan mereka dalam kegiatan-kegiatan keagamaan seperti membawa kitab suci, berpuasa dan sebagainya.

Dradjat (1978) mengemukakan bahwa tanggung jawab pendidikan Islam yang menjadi bahan orang tua sekurang-kurangnya harus dilaksanakan dalam rangka: 1)memelihara dan membesarkan anak. Ini adalah bentuk yang paling sederhana dari setiap orang tua dan merupakan dorongan alami untuk mempertahankan kelangsungan hidup manusia; 2) melindungi jasmani dan menjamin kesamaan, baik jasmani maupun rohani dari berbagai gangguan penyakit dan dari penyelewengan kehidupan dari tujuan hidup yang sesuai dengan falsafat hidup dan agama yang di anutnya; 3)memberi pengajaran dalam arti yang luas sehingga anak memperoleh peluang untuk memiliki pengetahuan dan kecakapan seluas dan setinggi mungkin yang dapat dicapainya; 4) membahagiakan anak baik di dunia maupun di akhirat, sesuai dengan pandangan dan tujuan hidup muslim.

Jalaluddin dan Said (1996: 92) dalam buku filsafat pendidikan Islam menjelaskan bahwa kepribadian muslim "sebagai identitas yang di miliki seseorang sebagai ciri khas dari keseluruhan tingkah laku secara lahiriah seperti cara bertutur sapa, berjalan, makan, minum, berhadapan dengan tamu, teman orang tua, guru dan famili maupun secara batiniah seperti penyabar, ikhlas, tidak dengki dan sifat terpuji lainnya yang muncul dan timbul dari dorongan batin."

Setiap orang tua menginginkan buah hatinya menjadi anak yang shalih dan shalihah, anak yang shalih dan shalihah merupakan harta yang paling berharga bagi orang tua. Untuk mendapatkan semua itu, tentu harus ada upaya keras dari orang tua dalam mendidik anak-anak, terutama sekali dengan cara pembinaan nilai-nilai agama sejak anak-anak.

Menurut Arifin (2000) pendidikan Islam merupakan suatu proses mengarahkan dan membimbing anak ke arah pendewasaan pribadi yang beriman, berakhlak dan berilmu pengetahuan yang saling mempengaruhi dalam perkembangannya untuk mencapai titik optimal.

Al-Abrasyi menyebutkan sebagaimana yang dikutip oleh Ramayulis (2008), pendidikan Islam adalah mempersiapkan manusia supaya hidup 
dengan sempurna dan bahagia, mencintai tanah air, tegap jasmaninya, sempurna budi pekertinya (akhlaknya), teratur pikirannya, halus perasaannya, mahir dalam pekerjaannya, manis tutur katanya baik dengan lisan maupun tulisan. Ketiga sarana pendidikan itu, orang tua, sekolah, dan masyarakat sangat perlu diperhatikan untuk mewujudkan manusia yang beriman, terampil, berakhlak mulia, disiplin, jujur, berani dan bertanggung jawab juga cinta tanah air. Ketiga sarana tersebut sangat besar pengaruhnya dalam membentuk dan membina keagamaan anak, seperti yang diungkapkan oleh Daradjat (1996) bahwa setiap pengalaman yang dialami anak dalam kehidupannya baik yang diterima melalui penglihatan, pendengaran, perlakuan yang diterimanya semua itu ikut menjalin bagian yang membentuk pribadinya.

Alquran adalah sumber utama ajaran Islam dan pedoman hidup bagi setiap muslim. Alquran bukan sekedar memuat petunjuk tentang hubungan manusia dengan Tuhan, tetapi juga mengatur hubungan manusia dengan sesama, serta hubungan manusia dengan alam di sekitarnya (Al-Munawwar, 2005). Keberadaan Alquran sebagai kitab suci umat Islam mempunyai posisi yang terpenting dan utama. Pentingnya Alquran dalam kehidupan umat Islam karena tindakan dan perbuatan harus disesuaikan dengan Alquran dan asSunnah. Dengan kata lain, Alquran merupakan panduan bagi umat dalam setiap melakukan perbuatan. Alquran merupakan sumber pedoman bagi umat Islam karena di dalamnya mengandung dan membawa nilai-nilai yang membudayakan manusia (Chalil, 1977).

Alquran harus dijadikan sebagai petunjuk dalam kehidupan manusia, maka Alquran harus dibaca, dipahami, dihayati, serta direnungkan segala isi yang terkandung di dalamnya. Manusia dituntut untuk melaksanakan perenungan secara mendalam dan memiliki kesanggupan untuk mengeluarkan bukti-bukti makna yang tersimpan di dalamnya, laksana mutiara yang tersimpan dalam kulit giwang di dasar lautan yang dalam.

Di dalam QS. Al-Ahzab: 59

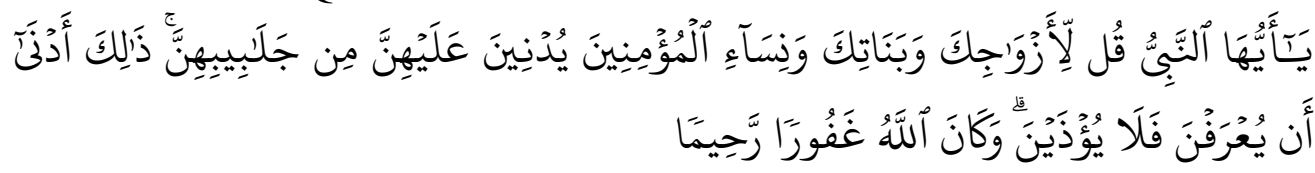

Artinya: "Hai Nabi, Katakanlah kepada isteri-isterimu, anak-anak perempuanmu dan isteri-isteri orang mukmin: "Hendaklah mereka mengulurkan jilbabnya ke seluruh tubuh mereka". Yang demikian itu supaya mereka lebih mudah untuk dikenal, karena itu mereka tidak di ganggu. dan Allah adalah Maha Pengampun lagi Maha Penyayang". (QS.Al-Ahzab:59) 
Ayat ini menjelaskan Allah SWT memerintahkah Rasullah saw supaya memerintahkan pula kepada istri-istrinya dan anak-anaknya yang perempuan, setelah itu kepada istri kaum muslimin supaya kalau mereka keluar rumah hendaklah memakai jilbab. Itulah sebab lanjutan ayat berbunyi “... yang demikian itu supaya mereka lebih mudah untuk dikenal, karena itu mereka tidak diganggu. Dengan tanda jilbab itu jelaslah bahwa mereka orang-orang terhormat. Dan Allah adalah maha pengampun lagi maha penyayang".

Hamka (1988) menjelaskan bahwa perintah mengenakan jilbab ini didahulukan kepada istri-istri beliau lalu anak-anak beliau karena ini akan menjadi contoh orang banyak. Setelah itu, baru kepada istri-istri dan anakanak orang yang beriman. Dalam konteks ayat ini terlihat bahwa salah satu konsep dalam pendidikan Islam adalah keteladanan. Yang dijadikan sebagai uswah adalah istri-istri dan anak-anak Nabi supaya ditiru oleh istri-istri dan anak-anak orang beriman lainnya. dan jika dibawakan pada konteks keluarga maka perintah Allah itu terlebih dahulu ditujukan kepada ayah yang nantinya akan menjadi uswah (teladan) bagi istri dan anaknya.

Shihab (2002) menyatakan dalam tafsir Al-Misbah bahwa ayat di atas memberikan tuntunan khusus kepada kaum mukminat untuk memakai jilbab. Hal ini bermula dari istri-istri nabi Muhammad saw yang di perintahkan mengenakan jilbab untuk menghindari sebab-sebab yang akan menimbulkan penghinaan dan pelecehan.

Dengan demikian, dari penjelasan Hamka (1988) dan Shihab (2002) atas surat Al-Ahzab di atas dapat dipahami sebagai ayat yang menjelaskan konsep keteladanan yang dimulai dari Rasulullah saw, lalu istri, dan kaum muslim. Berdasarkan uraian di atas, penulis menggambarkan urutan ketaudalanan dalam keluarga dimulai dari ayah, ibu dan anak lalu berlanjut kepada kaum muslimin (masyarakat). Istilah keteladanan banyak disinggung dalam Alquran, diantaranya adalah :

Tabel 1. Konsep keteladanan dalam Alquran

\begin{tabular}{ll}
\hline \multicolumn{1}{c}{ Konsep Keteladanan } & \multicolumn{1}{c}{ Lokasi Surat } \\
\hline Keteladanan Rasullah & Al-Ahzab 33:21 \\
Keteladanan nabi Yusuf dalam pergaulan & Yusuf 12:33-34 \\
Metode keteladanan dalam pendidikan Islam & Al-An'am 6:90, At-Taubah 9:00, At-Tur \\
& $52: 21$, Al-Hujurat 49:1, Ash-Shaf 61:2-3, \\
& Al-Mumtahanah 60:4-6 \\
Keteladanan akhlak & Al- Qalam 68:4, Al-Anbiya 21:107 \\
Keteladanan dalam memimpin & Al-Anfal 8:27 \\
Keteladanan dalam dakwah & Saba 34:28 \\
Keteladanan sebagai pendidik & Ash-Shaf 61:2-3, Al-Ahzab 33:40 \\
\hline
\end{tabular}

Ada beberapa penelitian relevan terkait keteladanan dalam pendidikan Islam. Penelitian Huzama (2012) fokus pada metode keteladanan dalam pendidikan 
Islam. Dia menjelaskan bahwa keteladanan mempunyai kedudukan yang sangat penting karena anak didik akan menilai dan meniru. Oleh karena itu, orang tua harus memahami dampak buruk dari hilangnya keteladanan dalam mendidik anak. Dalam Alquran ditegaskan dalam Surah Ash-Shaf ayat 2-3 bahwa perilaku seorang pendidik harus sejalan dengan apa yang ia katakan. Penafsiran Ayat-ayat Alquran tentang Pakaian oleh Mufasir Indonesia (Studi Komparatif Penafsiran Hamka dan Muhammad Quraish Shihab). Tesis: Syofrianisda, S.Th.I, M.A IAIN Iman Bonjol Padang 2012. Anik Listanti (229017), Mahasiswa Fakultas Tarbiyah dan Ilmu Keguruan Universitas Islam Nahdlatul Ulama' Jepara tahun 2013. Dengan judul "Konsepsi Zakiah Daradjat tentang Pendidikan Islam pada Anak dalam Keluarga".

\section{B. METODE PENELITIAN Jenis dan Metode Penelitian}

Penelitian ini adalah kajian pustaka (Library research). Penelitian ini dilakukan dengan menelaah buku-buku tafsir yang bersangkutan tentang konsep keteladanan dalam pendidikan keluarga. Fokus penelitian ini pada sumber utama, yaitu tafsir Al-Azhar dan tafsir Al-Misbah terkait penafsiran QS. Al-Ahzab : 59. Selain itu, peneliti juga memasukkan pendapat mufassir lainnya yang sepaham dengan kedua tafsir tersebut guna mendapat gambaran yang utuh yang kemudian dideskripsikan dan dianalisis sehingga memudahkan dalam menjawab persoalan yang telah dirumuskan dalam pokok masalah.

\section{Sumber Data}

Sumber data dalam penelitian ini adalah semua jenis bahan bacaan kepustakaan yang dikelompokkan sebagai sumber data primer dan sumber data sekunder.

Sumber data primer adalah sumber data yang menjadi bahasan utama dalam penelitian yang diperoleh dari kitab Tafsir Al-Azhar dan Tafsir AlMisbah serta buku-buku yang menjelaskan tentang penafsiran surat AlAhzab: 59 dan buku-buku yang menjelaskan tentang konsep keteladanan di dalam keluarga.

Sumber data sekunder dalam penelitian ini diperoleh dari berbagai bahan bacaan berupa buku pendidikan Islam, artikel di berbagai majalah, makalah, kajian-kajian Islam serta buku-buku lain yang berhubungan dengan penelitian ini, seperti artikel di majalah Hidayah, Hikayah, dan majalah Islam lainnya yang memiliki kajian khusus tentang keluarga sakinah.

\section{Teknik Pengumpulan Data}

Data dalam penelitian ini merupakan data kualitatif. Data dikumpulkan menggunakan metode Muqarran (perbandingan). Pengumpulan 
data dengan metode dokumentasi ini diperoleh dari sumber data berupa berbagai kitab, buku, jurnal ilmiah, makalah, ensiklopedi, website dan tulisan lain sesuai dengan tema yang diangkat. Langkah-langkah yang ditempuh adalah penelusuran data, pengumpulan, klasifikasi dan pengorganisasian data, reduksi data, dan display data.

Berdasarkan teknik pengumpulan data di atas, penulis sudah mempunyai konsep bahwa ketauladanan menjadi landasan sebagai basis pendidikan keluarga, dan pendidikan Islam sesuai dengan QS. Al-Ahzab: 59 dan dikaitkan dengan ayat-ayat lain yang menjelaskan tentang konsep keteladanan. Setelah bahan mengenai konsep keteladanan dikumpulkan dan data tentang pendidikan keluarga dan pendidikan Islam dicari, serta data-data yang berkaitan dengan keteladanan dalam pendidikan keluarga diperoleh, maka data tersebut dikelompokkan dalam pembahasan yang menerangkan tentang konsep keteladanan sebagai dasar pendidikan keluarga dan pendidikan Islam.

\section{Teknik Analisis Data}

Tahap analisis data merupakan tahapan yang sangat menentukan aspek penelitian berhasil atau tidak serta merupakan ujung tombak penelitian. Data yang terkumpul kemudian akan diperiksa, disaring, dan disusun dalam kategori, untuk selanjutnya dihubungkan satu sama lain (Rohidi, 1992).

Akan tetapi, tidak semua bidang kajian dari berbagai aspek akan dijadikan sasaran penelitian, hanya makna yang bersangkutan saja.

Kajian ini bersifat deskriptif analitis-komparatif, yaitu membandingkan metode yang dipakai oleh Shihab (2002) dan Hamka (1998), khususnya tafsir tentang konsep keteladanan dalam pendidikan keluarga. Penelitian ini pada dasarnya terfokus kepada sumber pokok yaitu Tafsir AlAzhar dan Tafsir Al-Misbah terhadap penafsiran QS, Al-Ahzab: 59. Peneliti juga memasukkan pendapat mufassir lainnya yang sepaham dengan kedua tafsir tersebut guna mendapat gambaran yang utuh, yang kemudian dideskripsikan dan dianalisis sehingga dapat memudahkan menjawab persoalan yang telah dirumuskan dalam pokok masalah dalam Alquran. Melalui metode komparatif ini, peneliti melihat perbandingan pandapat Shihab (2002) dan Hamka (1988) sehingga terlihat perbedaan maupun persamaan keduanya terutama dalam hal metodologi dan penafsirannya. Penelitian ini menggunakan pendekatan tematik untuk melihat dan memahami gambaran peristiwa masa lalu dan juga masa sekarang dalam mengungkap segi-segi sosial dari peristiwa yang terjadi. 


\section{HASIL PENELITIAN}

\section{Prinsip Keteladanan dalam Pendidikan Keluarga}

Dalam Kamus Besar Bahasa Indonesia, prinsip berarti asas, kebenaran, yang menjadi pokok dasar orang berpikir, bertindak, dan sebagainya. (Poerwadarmintha, 1991). Dalam pendidikan keluarga, prinsip berarti hal-hal yang menjadi dasar orang tua dalam penanaman nilai pendidikan kepada anaknya. Prinsip-prinsip dalam pendidikan keluarga akan tumbuh dan berkembang dengan adanya keteladanan yang baik. Salah satu firman Allah SWT yang menjelaskan keteladanan adalah surat Al-Ahzab: 59.

Firman Allah SWT dalam surat Al-Ahzab: 59 berbunyi:

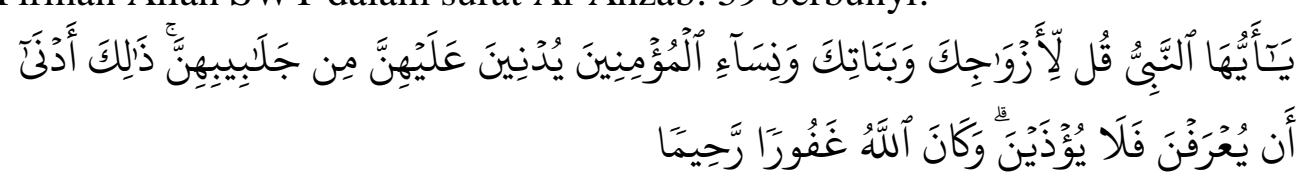

Artinya : "Hai Nabi, Katakanlah kepada isteri-isterimu, anak-anak perempuanmu dan isteri-isteri orang mukmin: "Hendaklah mereka mengulurkan jilbabnya ke seluruh tubuh mereka". Yang demikian itu supaya mereka lebih mudah untuk dikenal, karena itu mereka tidak di ganggu. dan Allah adalah Maha Pengampun lagi Maha Penyayang”. (QS. Al-Ahzab: 59)

Ayat ini menjelaskan perintah Allah SWT kepada Rasulullah saw agar supaya memerintahkan kepada istri-istrinya dan anak-anaknya yang perempuan, setelah itu kepada istri kaum muslimin supaya jika keluar rumah hendaklah mereka memakai jilbab. Hal ini berdampak pada lanjutan ayat berbunyi: yang demikian itu supaya mereka lebih mudah untuk dikenal, karena itu mereka tidak diganggu. Dengan tanda jilbab jelaslah bahwa mereka orang-orang terhormat." Dan Allah adalah Maha Pengampun lagi Maha Penyayang” (Shihab, 2000).

\section{Keteladanan Melalui Perintah Memakai Jilbab}

Di dalam ayat ini, jilbab ditulis dalam bentuk kata jamak yaitu "jalaabib" yang artinya jilbab-jilbab. Pengertian jilbab secara syariat Islam adalah pakaian wanita yang dapat menutup seluruh tubuh kecuali muka dan dua telapak tangan. Jenis kain dan potongan pakaian tersebut dibuat sedemikian rupa sehingga tidak tampak bentuk dan lekuk-lekuk tubuhnya yang dapat menimbulkan rangsangan. (Istadiyanta, 1991).

Kitab Al-Munjid mengartikan jilbab sebagai baju atau pakaian yang lebar. Dalam kitab Al-Mufradat, karya Raghib Isfahani, disebutkan bahwa jilbab adalah baju dan kerudung. Kitab Al-Qamus menyatakan jilbab sebagai pakaian luar yang lebar sekaligus kerudung yang biasa dipakai kaum wanita untuk menutupi pakaian (dalam) mereka. Kitab Lisanul Arab mengartikan 
jilbab sebagai jenis pakaian yang lebih besar ketimbang sekadar kerudung dan lebih kecil ketimbang selendang besar ( $r i d a$ '), yang biasa dipakai kaum wanita untuk menutupi kepala dan dada mereka (Darwis, 2001).

Sedangkan menurut Ibn Taimiyah dalam kitab Majmu' Al-Fatawa, jilbab adalah baju kurung yang menutupi seluruh tubuh. Abu Ubaidah dan lainnya menyebutkan, bahwasanya wanita (di zaman itu) mengulurkan jilbabnya dari atas kepalanya, dengan demikian tidak tampak melainkan matanya (Al-Fauzan, 2003).

Adapun jilbab pada masa Nabi saw ialah pakaian luar yang menutupi segenap anggota badan dari kepala hingga kaki perempuan dewasa. Menurut Ibnu Taimiyah dalam bukunya Hijabul Mar'ah Wa Libasuha Fish-Sholat, ia menyebutkan bahwa jilbab adalah pakaian yang juga mencakup khimar atau manutupi seluruh badan. Menurut penggunaan secara umum ia juga disebut izar yang bermakna longgar yang menutupi kepala dan seluruh badan (Shahab, 1986).

Memakai jilbab bagi wanita muslim merupakan syari'at yang diperintahkan oleh Allah dalam Alquran dan hadits karena melaksanakan perintah Allah agar wanita muslim mendapat pahala. Sebaliknya, bagi mereka yang menolak jilbab tanpa alasan yang dibenarkan oleh syara' termasuk kategori menentang Allah dan akan mendapat dosa. Oleh karena itu, tujuan berjilbab antara lain: a) melaksanakan ajaran agama secara kaffah (utuh); dan b) berpegang teguh kepada perintah Allah.

Umat Islam yang tetap berpegang teguh terhadap ajaran agama secara kaffah mulai berkurang sebab mereka tidak kuat dengan tantangan zaman yang ada. Contohnya, banyak wanita muslim yang rela melepas jilbabnya karena tuntutan pekerjaan, malu dengan teman, dan sebagainya. Dengan melihat fenomena tersebut maka wanita muslim yang berjilbab di tengahtengah masyarakat yang modern ini adalah wanita yang berusaha berpegang teguh kepada perintah agama. Disamping itu, kebutuhan terhadap pakaian merupakan kebutuhan yang mendesak karena pakaian berfungsi melindungi tubuh, menghindarkan penyakit, menutupi aurat, dan berfungsi sebagai perhiasan.

\section{Tahap-Tahap Keteladanan dalam Pendidikan Keluarga}

Keluarga sebagai lembaga (institusi) sosial pertama dan juga lembaga pendidikan pertama yang merupakan pondasi dan asas untuk terbentuknya masyarakat yang bermoral berawal dari keluarga yang bermoral. Sedang pendidikan Islam bertujuan untuk mewujudkan manusia bermoral yakni insan kamil yang bertakwa. Pendidikan dalam keluarga memerlukan keteladanan dari orang-orang yang menjadi figur di dalam keluarga. 


\section{Mulai dari diri sendiri (Ibda' binafsi)}

Untuk menjadi teladan, seseorang harus mendidik dirinya sendiri dengan cara menanamkan aspek yang terkandung dalam surat Al-Ahzab: 59 tersebut yaitu berbusana muslim atau berjilbab untuk menutup aurat dan untuk berhias. Memakai jilbab bagi wanita muslim merupakan syari'at yang diperintahkan oleh Allah dalam Alquran dan hadits. Karena melaksanakan perintah Allah maka wanita muslim akan mendapat pahala. Sebaliknya, bagi mereka yang menolak jilbab tanpa alasan yang dibenarkan oleh syara' termasuk kategori menentang Allah dan mendapat dosa. Dengan memulai dari diri sendiri akan memberikan keteladanan. Keteladanan akan memberikan kontribusi yang sangat berarti bagi tercapainya tujuan pendidikan kewajiban menutup aurat, begitu pula dalam hal pendidikan keluarga. Orang tua merupakan contoh teladan utama sebagai panutan bagi anak-anaknya, memegang teguh ketauhidan dan menjaganya, serta mengamalkan nilai-nilai keteladanan dari Rasullah saw dalam aspek menutup aurat di dalam keluarga.

\section{Lingkungan Keluarga sebagai Lembaga Pendidikan}

Pendidikan dalam keluarga adalah pendidikan keteladanan dari seluruh anggota keluarga yang di aplikasikan dan direalisasikan secara nyata pada setiap aspek kehidupan berkeluarga. Dengan demikian, sentral pendidikan adalah keluarga dan menjadi tanggung jawab anggota keluarga secara keseluruhan, tidak terbatas hanya orang tua saja. Sesuai dengan porsi dalam status dan kedudukannya, masing-masing bertanggung jawab atas perbuatannya untuk menanamkan kewajiban menutup aurat di lingkungan keluarga. Pendidikan keluarga adalah hal-hal yang menjadi tanggung jawab orang tua untuk diupayakan menyangkut hubungannya dengan anak-anaknya. Tanggung jawab orang tua terhadap anak merupakan hak anak atas orang tuanya. Dalam membangun keluarga sebagai salah satu institusi pendidikan yang kuat dan mendasar, peran kedua orang tua sangat menentukan, yaitu menjadi contoh dan suri teladan bagi anak-anaknya.

Salah satu aspek yang terkandung dalam surat Al-Ahzab: 59 adalah seruan atau perintah kepada Rasulullah saw yang merupakan teladan terbesar bagi segenap manusia. Beliau adalah seorang pendidik, da'i, pejuang, kepala rumah tangga, dan pemberi petunjuk bagi manusia dengan tingkah lakunya sendiri sebelum dengan kata-kata yang baik. Rasulullah saw merupakan teladan dalam masalah berpakaian bagi seluruh umat manusia.

\section{Pembiasaan sejak dini}

Pembiasaan sejak dini dalam menutup aurat merupakan proses penanaman kebiasaan, mengupayakan suatu tindakan agar terbiasa melakukannya, sehingga terkadang seseorang tidak menyadari apa yang 
dilakukannya sudah menjadi kebiasaan. Membiasakan anak untuk bertingkah laku, berbicara, berpikir dan berpakaian baik akan menjadi kebiasaan yang baik, sehingga menjadi teladan bagi yang lain.

\section{Keteladanan}

Pada diri anak terdapat potensi imitasi dan identifikasi terhadap orang yang dikaguminya seperti kepada orang tua. Oleh karena itu, orang tua harus mampu memberikan suri teladan yang baik dalam menutup aurat. Keteladanan ini sangat efektif digunakan sebagai contoh yang jelas untuk ditiru. Keteladanan merupakan salah satu metode yang ditunjukkan dalam Alquran yang terdapat pada pribadi Rasulullah saw. Melalui keteladanan beliau, ajaran agama Islam mudah diterima dan tersebar di seluruh penjuru dunia. Keteladanan terbagi atas dua macam, yaitu peneladanan yang disengaja dan peneladanan yang tidak disengaja. Peneladanan yang disengaja adalah peneladanan yang disertai dengan penjelasan atau perintah agar meneladani, seperti memberi contoh membaca yang baik dan benar, mengerjakan shalat dan lainnya. Sedangkan peneladanan yang tidak disengaja seperti keilmuan, kepemimpinan, sifat keikhlasan dan menutup aurat.

\section{Nasehat}

Nasehat merupakan metode yang efektif dalam usaha pembentukan keimanan, menanamkan nilai moral, spiritual dan sosial karena metode ini dapat membuka mata hati anak didik akan hakikat sesuatu serta mendorongnya menuju situasi luhur dan menghiasi akhlak mulia. Dengan demikian, nasehat adalah memerintah atau melarang yang disertai dengan pemberian motivasi atau ancaman. Nasehat juga mengandung arti mengatakan sesuatu yang benar dengan cara melunakkan hati. Penerapan metode nasehat dapat dilakukan secara langsung dan tidak langsung. Pemberian nasehat secara langsung misalnya dalam memberikan penjelasan pada anak didik tentang nilai-nilai yang baik, kurang baik atau tidak baik terhadap menutup aurat. Sedangkan nasehat secara tidak langsung, misalnya melalui cerita dan ungkapan metafor. Penggunaan metode nasehat sebaiknya tidak memakai pendekatan perintah maupun larangan, dan nasehat akan lebih baik jika dilakukan secara tidak langsung, karena dengan cara ini nilai-nilai yang ditransmisikan akan lebih mengesan bagi anak didik daripada dengan perintah maupun larangan.

Anak adalah mutiara yang menjadi kebanggaan orang tuanya. Anak juga merupakan permata yang diharapkan kelak akan mempu mengharumkan nama baik keluarga. Anak tetapi, yang lebih penting anak adalah amanat yang sangat agung dan mulia. Orang tua semestinya berbangga dan berbahagia telah dipercayai oleh Allah untuk memegang untuk memegang 
amanat tersebut. Sebagai perwujudan untuk memelihara amanat Allah tersebut maka sepatutnya orang tua mendidik anaknya sesuai dengan petunjuk yang telah disyari'atkan oleh Allah. Menurut Rasulullah saw, fungsi dan peran orang tua harus mampu untuk membentuk arah keyakinan anakanak mereka. Menurut Rasulullah saw, setiap bayi yang baru lahir sudah memiliki potensi untuk beragama, namun bentuk keyakinan agama yang akan dianut anak sepenuhnya tergantung dari bimbingan, pemeliharaan dan pengaruh kedua orang tua.

Orang tua banyak mempunyai peran dalam menumbuhkan anaknya agar tumbuh menjadi anak yang shaleh dan shalehah dambaan kebahagiaan setiap orang tua. Peran tersebut diantaranya, yaitu memulai dari diri sendiri, tidak bersikap kasar, menanamkan rasa percaya diri, tidak menjadikan anak sebagai pengekor, menjaga terus kemandirian anak, tidak berlebihan melindungi anak, mengembangkan jati diri anak. (Utsman, 2005).

Dengan demikian, peranan keteladanan diakui telah memiliki peran yang signifikan dalam usaha pencapaian keberhasilan pendidikan dalam menutup aurat dalam keluarga. Hal ini disebabkan karena secara psikologis, anak didik lebih banyak mencontoh perilaku atau sosok figur yang diidolakannya termasuk orang tuanya. Karena itu, seorang pendidik (orang tua) hendaknya menyadari bahwa perilaku yang baik dengan menutup aurat adalah tolak ukur yang menjadi keberhasilan bagi anaknya.

Selain itu, ibu adalah guru pertama bagi anak-anaknya dalam keluarga. Dari ibulah anak pertama kali belajar. Oleh sebab itu, ibu dituntut ekstra hati-hati karena dia mempunyai pengaruh yang besar pada anakanaknya. Ibu yang baik akan melahirkan generasi yang baik. Karena itu, tugas ibu dalam mendidik anak-anaknya adalah tugas yang sangat mulia, berat dan sangat menentukan. Figur ibu merupakan figur teladan bagi anakanaknya yang membentengi mereka dari pengaruh negatif dari luar.

\section{Peranan Keteladanan di dalam Pelaksanaan Ajaran Islam}

Dalam pendidikan berbagai cara dilakukan untuk mendidik, membimbing dan mengarahkan anak atau siswa dalam proses pembelajaran. Akan tetapi, yang terpenting adalah bagaimana orang tua, guru, ataupun pemimpin menanamkan rasa iman, cinta pada Allah, nikmatnya beribadah shalat, puasa, hormat dan patuh kepada orang tua, saling menghormati atau menghargai sesama, dan lain sebagainya. Hal ini agak sulit jika di tempuh dengan cara pendekatan empiris atau logis.Untuk merealisasikaanan tujuan pendidikan, seorang pendidik dapat saja menyusun sistem pendidikan yang lengkap, dengan menggunakan seperangkat metode atau strategi sebagai pedoman atau acuan dalam bertindak serta mencapai tujuan dalam pendidikan (Tafsir, 2000). Namun keteladanan seorang pendidik sangatlah penting dalam interaksinya dengan anak didik. Karena pendidikan tidak 
hanya sekedar menangkap atau memperoleh makna dari sesuatu dari ucapan pendidiknya, akan tetapi justru melalui keseluruhan kepribadian yang tergambar pada sikap dan tingkah laku para pendidiknya (Nawawi, 1993) Dengan demikian peranan keteladanan antara lain adalah:

\section{Keteladanan sebagai metode dalam pendidikan Islam}

Metode pendidikan dengan keteladanan berarti pendidikan dilakukan dengan memberi contoh, baik berupa tingkah laku, sifat, cara berpikir, dan sebagainya. Banyak ahli pendidikan yang berpendapat bahwa pendidikan dengan teladan merupakan metode pendidikan yang paling berhasil guna. Hal itu karena dalam belajar, orang pada umumnya, lebih mudah menangkap yang kongkrit ketimbang yang abstrak. Penggunaan keteladanan sebagai sebuah metode pendidikan juga terlihat dari teguran Allah SWT terhadap orang-orang yang menyampaikan pesan, memberikan pendidikan kepada orang lain akan tetapi tidak mengamalkan muatan pesan pendidikan itu sendiri sebagai mana terdapat dalam Alquran surat Ash-Shaff: 2-3
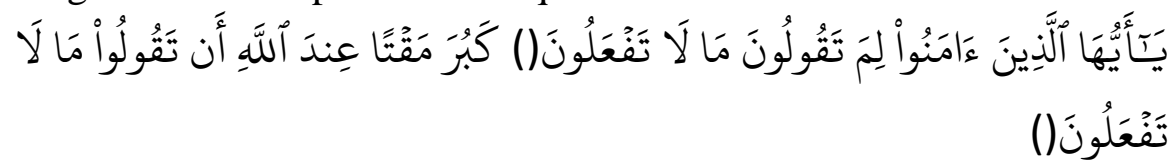

Artinya :Wahai orang-orang yang beriman, kenapakah kamu mengatakan sesuatu yang tidak kamu kerjakan?Amat besar kebencian di sisi Allah bahwa kamu mengatakan apa-apa yang tidak kamu kerjakan.(QS. Ash-Shaff:2-3)

Firman Allah SWT di atas memberi pelajaran kepada setiap pendidik supaya tidak hanya mampu memberi teori, tapi juga dapat menjadi panutan bagi anak didiknya. Amat tercela sikap seorang pendidik yang mengajarkan suatu kebaikan sedangkan ia sendiri tidak menerapkan dalam kehidupan sehari-harinya. Orang seperti inilah yang dibenci oleh Allah SWT karena bahkan anak didiknya tidak menghormati pelajaran yang diajarkannya. Dengan demikian, keteladanan dalam pendidikan merupakan bagian dari sejumlah metode yang paling ampuh dan efektif dalam mempersiapkan dan membentuk anak secara moral, spiritual, dan social, sebab seorang pendidik merupakan contoh ideal dalam pandangan anak, yang tingkah laku dan sopan santunnya akan ditiru. Semua keteladanan itu akan melekat pada diri dan perasaannya, baik dalam bentuk ucapan, perbuatan, hal yang bersifat material, inderawi, maupun spiritual. Meskipun anak berpotensi besar untuk meraih sifat-sifat baik dan menerima dasar-dasar pendidikan yang mulia, ia akan jauh dari kenyataan positif dan terpuji jika dengan kedua matanya ia melihat langsung pendidikan yang tidak bermoral. Yang mudah bagi pendidik adalah mengajarkan berbagai teori pendidikan kepada anak, sedang 
yang sulit bagi anak adalah mempraktekkan teori tersebut jika orang yang mengajar dan mendidiknya tidak pernah melakukannya atau perbuatannya tidak sesuai dengan ucapannya (Ulwan, 1992).

\section{Keteladanan sebagai media dalam pendidikaan dan pengajaran agama Islam}

Media adalah segala sesuatu yang dapat menyalurkan pesan yang dapat merangsang pikiran, perasaan, dan kemauan anak dan siswa sehingga dapat mendorong terjadinya proses belajar pada dirinya (Asnawir \& Usman, 1999). Bila dikaitkan dengan keteladanan berarti dengan media keteladanan akan memudahkan bagi anak dan siswa dalam memahami pelajaran dan ini telah dicantumkan oleh Allah SWT dalam al-Quran pada kisah Qabil dan Habil sebagaimana di digambarkan dalam surah Al-Maidah: 30-31 sebagai berikut:

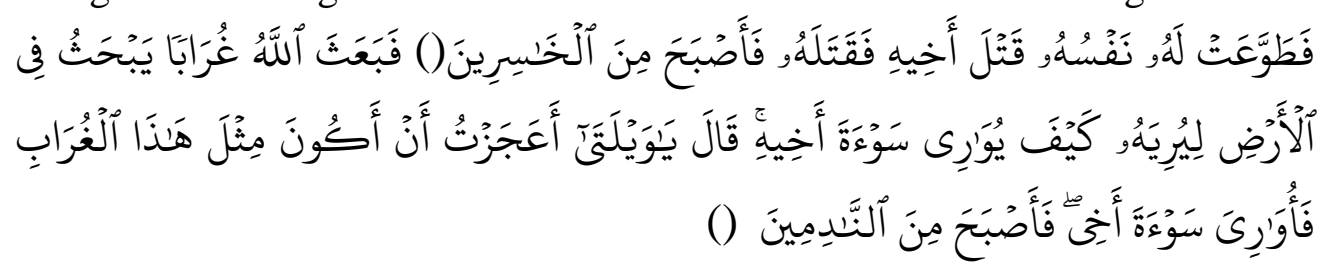

Artinya: "Maka hawa nafsu Qabil menjadikannya menganggap mudah membunuh saudarannya, sebab itu dibunuhnyalah, maka jadilah ia seorang di antara orang-orang yang merugi, kemudian Allah SWT menyuruh seekor burung gagak menggaligali di bumi untuk memperlihatkan kepadanya (Qabil) bagaimana seharusnya menguburkan mayat saudaranya.... (QS. Al-Maidah: 30-31)

Dengan demikian, peristiwa pembunuhan yang diikuti penguburan yang dilakukan didalamnya terhadap saudaranya (Habil),media pembelajaran itu dapat simak lewat tingkah laku burung gagak yang menggali tanah untuk mengubur gagak yang lain, (Mujid, 2006) Perbuatan burung gagak itu ditiru oleh Qabil yang sedang bingung memikirkan apa yang akan dilakukannya terhadap mayat saudaranya, begitu besar hikmah yang diberikan Allah kepada pembunuh (Qabil) dengan menurunkan seekor burung gagak memberi contoh, sehingga Qabil menemui jalan keluar.sehingga dengan memahami kandungan penjelasan ayat diatas pengunanaan media keteladanan sangat memudahkan bagi pendidik, orang tua dalam mengajarkan ajaran Islam.

\section{PENUTUP}

Keluarga ialah orang-orang yang terdekat, yang terdiri atas ayah, ibu dan anak, yang memiliki peranan dalam pendidikan dan tingkah laku 
seseorang, dan mempunyai tujuan untuk mencapai kebahagiaan dunia dan akhirat.

Prinsip keteladanan dalam pendidikan keluarga berdasarkan QS. Surat Al-Ahzab: 59 menjelaskan bahwa Rasulullah saw dalam menyampaikan ajaran islam berupa pemakaian jilbab memiliki keteladanan. Rasulullah saw tidak langsung menyuruh seluruh umat Islam untuk memakai jilbab, namun meyuruh keluarga terdekatnya terlebih dahulu, yaitu isteri-isterinya dan anakanaknya.

Tahap-tahap dalam pemberian keteladanan berdasarkan Alquran surat Al-Ahzab: 59 dibagi atas tiga tahapan. Tahap awal adalah dimulai dari sendiri, selanjutnya tahapan kedua adalah lingkungan keluarga, dan tahapan ketiga adalah pendidikan ajaran Islam terhadap masyarakat.

\section{DAFTAR PUSTAKA}

Al-Fauzan, S. F. A. (2003). Sentuhan nilai kefikihan untuk wanita beriman. Jakarta: Media Dakwah.

Al-Munawwar, S., A. H. (2005). Al-Qur'an membangun tradisi kesalehan yang hakiki. Ciputat: PT Ciputat Press.

Arifin, M. (2000). Kapita selekta pendidikan Islam dan umum. Jakarta: Bumi Aksara.

Asnawir \& Usman, M. B. (1999). Media pengajaran. Padang: IAIN "IB" PRES.

Asy-Syantuh, K. A. (1993). Pendidikan anak putri dalam keluarga muslim. Jakarta: Pustaka Al-Kautsar.

Chalil, M. (1977). Kembali kepada Al-Qur'an dan Sunnah. Jakarta: Bulan Bintang.

Darwis, K. B. A. K. (2001). Bagaimana muslimah bergaul. Jakarta: Pustaka Al-Kautsar.

Daradjat, Z. (1987). Membina nilai-nilai moral Indonesia. Jakarta: Bulan Bintang.

Djaelani, A. Q. (1995). Keluarga sakinah. Surabaya: PT. Bina Ilmu. 
Hamka. (1987). Iman dan amal sholeh. Jakarta: Pustaka Panji Mas.

Hamka. (1988). Tafsir al-Azhar. Jakarta: Panjimas.

Hapizh, M. N. A. (1997). Mendidik anak bersama Rasulullah. Bandung: AlBayan.

Istadiyanta, (1991). Hikmah busana muslimah dalam pembinaan akhlak. Solo: Ramadhani.

Jalaluddin. (2002). Mempersiapkan anak shaleh, Jakarta: Rosdakarya.

Jalaluddin \& Usman, S. (1996). Filsafat pendidikan Islam konsep perkembangan pemikirannya. Jakarta: PT. Raja Grapindo.

Jamaluddin Hamidi, DKK, Shaheh Bukhari, Jakarta: Wijaya, 1984

Mujid, A. (2006). Ilmu pendidikan Islam. Jakarta: Kencana.

Nawawi, H. (1993). Pendidikan dalam Islam. Surabaya: Al Ikhlas.

Poerwadarmintha, W.J.S. (1991). Kamus besar bahasa Indonesia. Jakarta: Balai Pustaka.

Ramayulis, (1994), Pengantar ilmu pendidika Islam, Jakarta: Kalam Mulia.

Ramayulis. (2008). Ilmu pendidikan Islam. Jakarta: Kalam Mulia.

Rohidi, T. R. (1992). Qualitative data analysis. Jakarta: UI-Press.

Shahab, H. (1986). Jilbab menurut Alqur'an dan As-Sunnah. Bandung: Mizan.

Shihab, M. Q. (2000). Tafsir Al-Misbah. Jakarta: Lentera Hati.

Shihab, M. Q. (2002). Tafsir Al—Misbah, Jakarta: Lentera Hati.

Tafsir, A. (2000). Ilmu pendidikan dalam perspektif Islam. Bandung: Remaja Rosdakarya.

Ulwan, A. N. (1992). Pendidikan anak menurut Islam: Kaidah-kaidah dasar. Bandung: PT Remaja Rosdakarya. 
Undang-undang RI No. 20 Tahun 2003, Tentang Sistem Pendidikan, Jakarta: Sinar Grafika.

Utsman, S. A. M. (2005). Cara mencetak anak tangguh. Jakarta: PT. Pustaka Al-Kautsar.

Zaini, S. (1983). Kuliah aqidah Islam. Surabaya: Al-Ikhlas.

Zakiyah Daradjad, Ilmu Jiwa Agama, Jakarta: Bulan Bintang, 1996 